\title{
A well-preserved partial skeleton of the poorly known early Miocene seriema Noriegavis santacrucensis
}

Gerald Mayr and Jorge I. Noriega

Acta Palaeontologica Polonica 60 (3), 2015: 589-598 doi:http://dx.doi.org/10.4202/app.00011.2013

Seriemas (Cariamidae) include two extant species, Cariama cristata and Chunga burmeisteri, which live in semi-open plains of South America and have a poorly documented evolutionary history. One of the earliest fossil representatives of Cariamidae is the recently described Noriegavis santacrucensis from the early Miocene Santa Cruz Formation (Argentina). So far, however, this species was only known from a cranium and tentatively referred distal tibiotarsi, and its phylogenetic assignment has been questioned. Here we describe a well-preserved partial skeleton from the Santa Cruz Formation, which substantiates the classification of Noriegavis in Cariamidae. Plesiomorphic features show $N$. santacrucensis to be outside crown group Cariamidae, but the species is nevertheless very similar to its modern relatives and documents that the osteology of seriemas underwent only few changes during the past 16 million years.

Key words: Aves, Cariamiformes, Cariamidae, Miocene, Santa Cruz Formation, Argentina.

Gerald Mayr [Gerald.Mayr@senckenberg.de], Senckenberg Research Institute and Natural History Museum Frankfurt, Ornithological Section, Senckenberganlage 25, D-60325 Frankfurt am Main, Germany; Jorge I. Noriega [cidnoriega@infoaire.com.ar], Laboratorio de Paleontología de Vertebrados, CICYTTP-CONICET, Materi y España, (3105) Diamante, Entre Ríos, Argentina.

This is an open-access article distributed under the terms of the Creative Commons Attribution License (for details please see creativecommons.org), which permits unrestricted use, distribution, and reproduction in any medium, provided the original author and source are credited. 
Faris Full text $(639.0 \mathrm{kB})$ ।

Forif Supplementary file $(95.5 \mathrm{kB})$ 